\title{
Association of owner related and external factors with micro and small manufacturing enterprises growth in Ethiopia
}

\author{
Tesfaye Ginbare Gutu*; Abebe Shentema Yali
}

Department of Accounting and Finance, Business and Economics College, Jimma

University, Ethiopia

*To whom correspondence should be addressed.Email: tesfayeoli@gmail.com

\begin{tabular}{|l|l|l|l|l|}
\hline DOI: & Received: & Revised: & Accepted: & Published: \\
$10.22437 / p p d . v 8 i 2.9285$ & 11.05 .2020 & 20.05 .2020 & 23.05 .2020 & 12.06 .2020 \\
\hline
\end{tabular}

\begin{abstract}
This study was conducted with the objective of analyzing the association of owner related and external factors with growth of MSEs operating in the manufacturing sector. Primary data were collected from 218 randomly selected owner/operator of manufacturing MSEs and coordinators of MSEs by using structured questionnaire and interview, respectively. Chi-square test was employed to analyze the owner related/internal factors, and external factors with growth of manufacturing MSEs. The statistical test revealed that gender, initial investment size, modern machinery, training, infrastructure and location have statistically significant association with growth of manufacturing MSEs; whereas age, education level, work premises and market linkage/ access are found to have statistically insignificant association with growth of MSEs operating in the manufacturing sector, though they make difference on the MSEs growth level. Therefore, to improve the growth of manufacturing MSEs, MSEs development office in collaboration with the municipality, among others, should consider the statistically significant factors and focus on the MSEs' challenges which are stated by the owners of the business (own working premise and market access/linkage) and take corrective actions. Finally, further research on similar area is suggested by considering factors that need solution such as previous experience of operator in the sector, firm age and access to credit; besides similar study on remaining MSEs sector and comparative study may be conducted even within the manufacturing sector as economic sub-sector (i.e., textile and garment, metal working workshop, furniture and wood working, manufacturing bricks etc.) in order to have a holistic understanding of about the determinants of manufacturing MSEs growth
\end{abstract}

Keywords: Chi-square, Growth, Manufacturing sector, MSEs

JEL Classification: L25, L26, O14

\section{INTRODUCTION}

Micro and small enterprises play vital roles in poverty reduction, income and employment generation as well as economic development in developing countries like Ethiopia. The sector is now increasingly recognized unlike the previous pessimist notion that these sectors are not linked to the modern and formal sectors and would disappear once industrial development is achieved (McPherson, 1996). Therefore, in many 
countries they have been the major engine of growth in employment and output (Effective Policies for Small Business, 2004). According to Fisseha (2006); as cited in Admasu (2012), MSEs employ around 22 percent of the adult population in developing countries. Thus, MSEs are considered as quick remedy of unemployment problem (MoTI, 1997).

Ethiopia has prioritized on MSE development for economic growth, employment generation and building an industrial economy. To this end, in 1997 the government has designed a National MSEs development and promotion strategy which was reviewed in 2011 in view of the country's dynamic economic progress, program feedback and experience of other countries (MoTI, 2011), which facilitates and paves the ground for the growth and development of the sector with the primary objective of creating a favorable environment for MSEs so that MSEs could facilitate economic growth, create long-term jobs, strengthen cooperation between MSEs, provide the basis for medium and large scale enterprises and promote export. In this strategy framework, the government prioritized those enterprises with features like manufacturing and processing various commodities, self-employment particularly by disabled and unemployed youth, start-ups and expanding firms owned by women etc (Berihu, Abebaw, \& Biruk, 2014).

Special attention has been given at all levels to untie the constraints of MSEs for they are important vehicles to address the challenges of unemployment, economic growth and equity in the country. The government of Ethiopia has been implementing and incorporating the program as a strategic agenda in three consecutive five years national developmental plans of the country i.e. the $1^{\text {st }}$ five years plan called Poverty Reduction and Sustainable Development Program (PRSDP), in the $2^{\text {nd }}$ five years plan called Plan for Accelerated and Sustainable Development to End Poverty (PASDEP) and in the $3^{\text {rd }}$ five years plan which is called Growth and Transformation Plan (GTP) covering the years from 2010/11 to 2014/15 (MoFED, 2011), and currently the $2^{\text {nd }}$ part of five years plan Growth and Transformation Plan (GTP). In view of this, the government is implementing different support service programs in different parts of the country for helping MSEs attain their intended objectives.

Ensuring that Micro and Small Enterprises (MSEs) fully participate is a key to the large-scale uptake of sustainable practice. Sustainable development is highly demanding in particular on manufacturing firms, including MSEs, as their economic importance is higher. In Ethiopia, for example, as discovered by the CSA survey of 2003, MSEs account for the bulk of non-agricultural economic activities and nearly $95.6 \%$ of total industrial employment. Despite the large number, the MSE sector in Ethiopia is exposed to a number of constraints related to policy, and structural and institutional problems that hinder sustained growth, development and long-term planning (Amha \& Ageba, 2006).

Various studies have been conducted on MSEs in Ethiopia. The major focuses of these study subject are on (1) nature and characteristics of MSEs and their operators (Assefa, Zerfu \& Tekle, 2014; Saravanan, Mohideen \& Seid, 2014); (2) access to finance for MSEs (Selamawit, Aregawi \& Negus, 2014); (3) the social and economic role of MSEs (Berhanu, 2014; Kidane, Hepelwa, Mdadila \& Leel, 2015; Tasisa, 2014; Bereket, 2010 and Worku, 2004); (4) the performance of MSEs (Hailu, 2010; FeDRE, 2013; Sherefa, 2012; Abera, 2012 and Netsaalem, 2011); (5) the efficiency of micro finance institutions and other relevant bodies (Deribie, Negussie \& Mitiku, 2013 and World Bank Group, 2013); (6) external factors and success factors on developments and growth of MSESs and women and youth owned MSEs (Haftom, 2013; Hailay, 2014; Habtamu, 2012; Arega, Muhammed, \& Daniel, 2016; Lilian, 2013; Berhanu, 2014;Zemenu, Mohammed, 2014 and Berihu, Abebaw \& Biruk, 2014 ) and (7) challenges and opportunities of MSEs (Desalegn, 2013; Bizusew, 2015; Ruth, 2013 and Mukund, 2013). 
Moreover, almost all of the previous studies were conducted not in a sector wise, because some problems are specific to a given sector. Their focuses were in general all sector altogether but not in sector by sector (as manufacturing, construction, service, trade and industry, etc). It is difficult to generalize that the identified determinants ofMSEs growth of all individually owned enterprises across the sector are equally affect the growth of MSEs. Therefore, this study was conducted with the objective to analyzing the association of owner related and external factors with growth of micro and small manufacturing enterprises taking the case of selected towns of central administrative zone of Tigray regional state.

\section{METHODS}

This section presents the research approach, description of the data type, data sources, method of data collection, sampling design, sample size and method of data analysis. Given the objectives and nature of this study, the study has applied an explanatory type of research that determine the association between the dependent and independent variables by using cross sectional data collected from the sample respondents.

\section{Target population}

The target population of the study includes the owners/operators of micro and small enterprises engaged in manufacturing sectors located in selected study area that have been in business for a minimum of two years.

\section{Data type, sources and collection instruments}

This study had used primary sources of data. It employed cross-sectional data sourced from primary source of data. This is mainly due to the difficulties encountered in surveying large samples of the same respondents over time because of high firms entering and exiting the market. Besides, both qualitative and quantitative types of data have been used for this study. In this study the required data have been collected through questionnaire and interview instruments: Questionnaire: both close ended and openended structured questionnaires have been prepared and personally distributed by data collectors for the owners/operators of the MSEs to collect relevant data for the study.

\section{Sampling design and size}

A sample design is a definite technique that is adopted in selecting a sample from a given population. Among the major towns found in central zone, Aksum, WukroMaray, Adwa and Abiy Addi towns are selected purposively as a study area for this study. This because first central zone is the mandate zone of the university and these towns found in this zone believed can represent the remaining towns in the zone, and it is very difficult to address all small towns found in the zone to conduct quality research. To get a sample size from each town, the total MSEs registered before two years (before 2017) are identified. Then out of these total populations of the study the sample size are selected by applying a simplified scientific formula provided by Yemane (1997).

$$
n=\frac{N}{1+N(e)^{2}}
$$

Where; $\mathrm{n}$ is the sample size, $\mathrm{N}$ is the total Manufacturing MSEs in the selected towns. The unit of analysis of the study was the individual owner of enterprise. The investigators decided the confidence level of the study to be at $95 \%$ consequently the level of precision (e) is $5 \%$. 
According to the above-mentioned equation the MSEs owners that have been questioned were 218. Drawn using proportionate sampling technique 62 MSEs owners, 61 MSEs owners, 24 MSEs owners and 71 MSEs owners (total 218) from Aksum Town, Adwa Town, WukroMaray Town and Abiy Addi Town, respectively, has been questioned.

\section{Method of data analysis and presentation}

This study has applied the Chi-square test to test the statistical association of owner related and external factors with growth of MSEs operating in the manufacturing sector.

\section{Definition of variables}

Once the analytical procedure and its requirements are known, it is necessary to identify the potential explanatory and dependent variables, and describe their measurements. Deferent variables are expected to have association with growth of MSEs. The variables in this study are of two types: dependent variable (the growth of manufacturing MSEs) and independent or explanatory variables (internal and external factors).

In this study change in the number of employees was used as a dependent variable to measure the growth of manufacturing MSEs. Hence, employment growth is computed following the Evans (1987) model, i.e. firmgr $=(\ln S t '-\ln S t /$ firma $)$ Where, firmgr $=$ firm growth, $\operatorname{lnSt} t^{\prime}=\ln$ of current employment, $\operatorname{lnSt}=\ln$ of initial employment and firma $=$ firm age.

Independent variables are variables that are expected and have more explanatory power on the dependent variable, i.e., growth of manufacturing MSEs.vThese are owner related/internal factors, i.e., age, gender, education level, initial investment size, availability of machinery and external factors, i.e., access to working premise, market access or linkage, infrastructure facilities (electricity, water, road facility), business or technical training and location of business. The expected effects of these factors on the growth of manufacturing MSEs are discussed in the following section.

Age:Due to the reason that the younger owner/operator has the necessary motivation, energy and commitment to work and is more inclined to take risks, many previous empirical studies indicated that the younger owner/manager of MSEs is more likely to grow than the counterpart (Kokobe, 2013 and Hailay, 2014). Thus, in this study age of the owner is predicted to have a negative impact on the growth of manufacturing MSEs.

Gender:It indicates whether the owner is male or female. Male ownedfirms may have more opportunities to develop as a result of male may have higher networks to get assistance may have lesser difficulty in assembling resources. Since women are more family oriented, concentrated in more slowly growing sectors and more risk-averse, empirical studies (Habtamu, 2012; Haftom, 2013; Ishengoma \& Kappel, 2008; Kokobe, 2011; Hailay, 2014; and Mulu, 2007) found that Male-headed firm's grow faster than that of female headed. On the other hand, Chirwa (2008) indicated that female-owned enterprises tend to grow more rapidly in terms of employment than male-owned ones.

Education level: Owners of MMSEs with a higher formal education and training would be expected to grow faster than their counterpart (Harding, 2002). In consistent to this theory, some empirical studies (Ahiawodzi \& Adabe, 2012; and Mulu, 2007) found that the growth of MSEs improves with increasing in education. In contrast, there were also studies which found education is insignificant in determining the growth of MSEs (Hove \& Tarisai, 2013; and Kokobe, 2013). Hence, in this study education level of the owner is predicted to have a positive impact on the growth of manufacturing MSEs 
Initial investment size: Clover \& Darroch (2005) reported that funding constraints at start-up highly affects the growth of MSEs. In other words, start- up capital of a given firm has significant positive effect on the growth of MSEs (Ahiawodzi \& Adabe, 2012; Habtamu, 2012; Hailay, 2014 and Haftom, 2013). Similarly, in this study, it is predicted that the size of initial investment size has a positive impact on manufacturing MSEs growth.

Availability of modern machinery: According Belay, Asmera \& Tekalign (2015), MSEs that lacked modern machinery and equipment have shown limited growth and expansion. Similarly, in this study, it is predicted that having modern machinery for the intended business operative has a positive impact on manufacturing MSEs growth.

Access to working premises: MSEs that have own premise is positively associated with its growth. Manufacturing business enterprises need enough working and marketing place for their product and services. Unless having enough working and selling place, the productivity of manufacturing MSEs go down due to the fact that the product produced need warehouse to store and selling outlets to rich in the hands of final customers which is major determinant for existence and growth of the enterprises. The empirical study of (Haftom, 2013) showed that MSEs operators that secure own working place and buildings are in a better position to plan with greater certainty and stand a better chance of accessing the needed infrastructure and in doing so will enhance the growth of such enterprises. Thus, own premise is expected to have positive association with Manufacturing MSEs growth.

Technical and business management training: Studies conducted by Dagmawit \& Yishak (2016); and Arega, Muhammed, \& Daniel (2016), attending technical and business management training positively affect the growth of MSEs. Whereas, studies conducted by Garoma (2012), found insignificant association between Entrepreneurial training of the owner and success or growth on micro enterprises. Thus, in this study those manufacturing MSEs that have attended technical and business management training are more likely to grow as compared to others

Market linkage: According to Mbugua, Mbugua, Wangoi, Ogada, \& Kariuki. (2013), marketing has a major effect on the growth of MSEs.MSEs that have good market linkage exhibit higher growth compared to MSEs that have no good market linkage (Belay, Asmera \& Tekalign, 2015). Further, Kinda \& Loening (2008) reported that lack of basic raw materials and their higher cost affects the growth of the MSEs. In consistent to these findings many studies (Admasu, 2012; Hove \& Tarisai, 2013; Kefale \& Chinnan, 2012; and Kokobe, 2013) indicated the positive effect of marketing issues. Similarly, in this study, it is predicted that the market linkage has a positive impact on manufacturing MSEs growth.

Access to infrastructure: Nonexistent of basic infrastructure such as, inability to access power, water, road etc have a large impact on the growth of manufacturing MSEs (Hailay, 2014; Admasu, 2012; Clover \& Darroch, 2005; Haftom, 2013; Kinda \& Loening, 2008; and Osotimehin, Jegede, Akinlabi, \& Olajide, 2012). Similarly, in this study access to infrastructure is expected to have a positive impact on manufacturing MSEs growth.

Location: MSEs located at main road side exhibit higher growth compared to MSEs located out of town (Habtamu, 2012; Hasnu \& Amjam, 2007). Therefore, in this study operating at busy street is expected positively affect MSEs growth.

Thus, to investigate the association of internal and external factors with growth status of manufacturing MSEs, the following equation is estimated to examine the relation of each factor with growth of MSEs (number of employees). The equation is specified as follows: 


$$
\begin{aligned}
\operatorname{Pr}(\mathrm{Y}=1)= & \beta_{0}+\beta_{1}(\text { Age })+\beta_{2}(\text { Gndr })+\beta_{3}(\text { Ednlvl })+\beta_{4}(\text { InitInv })+\beta_{5}(\text { Machnry })+\beta_{6}(\text { Acswp }) \\
& +\beta_{7}(\text { Mrkta })+\beta_{8}(\text { Infr })+\beta_{9}(\text { Trnng })+\beta_{10}(\text { Loctn })+\varepsilon_{1} \ldots \ldots \ldots \ldots \ldots \ldots \ldots \ldots \ldots . . . \ldots \ldots \ldots \ldots \ldots \ldots
\end{aligned}
$$

Where;

$\beta_{0}=$ Constant (intercept)

$\beta_{1}, \beta_{2} \ldots \beta_{10}=$ slope coefficients of independent variables (the unknown parameters that reflecting the impact of change in independent variables).

$\varepsilon_{\mathrm{i}}=$ Error term

$\mathrm{Y}=$ Manufacturing MSE's growth

Age $=$ Age of owner operator

Gndr= Gender of MSEs owner/operator

Ednlvl = Education level of owner operator

InitInv= Size of the initial investment by the owners

Machnry= Availability of machineries

Acswp $=$ Access to Working Premise

Mrkta $=$ Market access.

Infr= Infrastructure facilities (electricity, water, Road Facility)

Trnng $=$ owner attended business and technical training or not

Loctn=LocationMSEs located at main road side versus located out of main road

\section{RESULT AND ANALYSIS}

For the purpose of analyzing the association of owner related and external factors with growth of MSEs operating in the manufacturing sector which are found in the selected towns of central administrative zone of Tigray region (i.e., Aksum, WukroMaray, Adwa and Abiy Addi towns) were taken as a target population for this study. Primary data was collected from 218 MSEs functioning in manufacturing sector. Using the manufacturing MSEs growth status as a dependent variable where by a value of 1 is given to grown manufacturing MSE and 0 to non-grown/survival manufacturing MSE taking the employment growth rate in to account.

\section{General characteristics of the enterprises}

Micro and small enterprises are generally categorized in to two: micro and small enterprises. As per to Table 1, most 134 (61.47percent) of the surveyed enterprises in selected towns of Central administrative Zone of Tigray Region were micro enterprises and the remaining 84 (38.53 percent) were small enterprises. This shows that majority of the enterprises of the selected towns were categorized under the micro enterprise. This result is consistent with the findings of MoTI (1997) which found 90 percent micro and 10 percent small enterprises conducted in 48 major Ethiopia towns, Hailay (2014) found 80 percent micro and 20 percent small enterprises in Feresmay Town, and Kefale \&Chinnan (2012) found 73 percent micro and 27 percent small enterprises in Woldiya Town.

Table 1. Category of mmanufacturing MSEs in selected towns of Central Administrative Zone of Tigray

\begin{tabular}{lcc}
\hline Enterprise type & Number of enterprises & Percent $(\%)$ \\
\hline Micro & 134 & 61.47 \\
Small & 84 & 38.53 \\
\hline Total & 218 & 100.00 \\
\hline
\end{tabular}

Source: Own Survey Data (2019) 


\section{Status of manufacturing MSEs in selected towns of central administrative zone of Tigray}

To determine the status of manufacturing MSEs, information on the growth measure has to be collected and an appropriate measure of aggregate growth has to be used. As a result, from the available alternatives of aggregate growth measures (capital, sales, profit, employment and etc) that are discussed in literature, this study used employment size as an objective measure of firm growth since the data used in this study rely on a recall basis as a result other measures are susceptible to measurement errors. Accordingly, manufacturing MSEs growth rate is computed by taking the natural logarithm of change in employment size over the life of the firm [i.e., $\boldsymbol{g} \boldsymbol{r}=\frac{\boldsymbol{l n} \boldsymbol{s} \boldsymbol{t}^{\prime}-\boldsymbol{l n} \boldsymbol{s t}}{\boldsymbol{e n t a g e}}$ ] following Evans (1987) model. Taking the calculated growth rate, the manufacturing MSEs are classified in to two broad categories i.e., grown (if growth rate $>0$ ) and nongrown or survival (if growth rate $\leq 0$ ) following Cheng (2006) growth classification. Thus, out of the total sample 55.96 percent are found survival type (122 MSEs) and the remaining 44.04 percent (96MSEs) are found grown type. The following Figure 1 shows status of manufacturing MSEs in the selected towns.

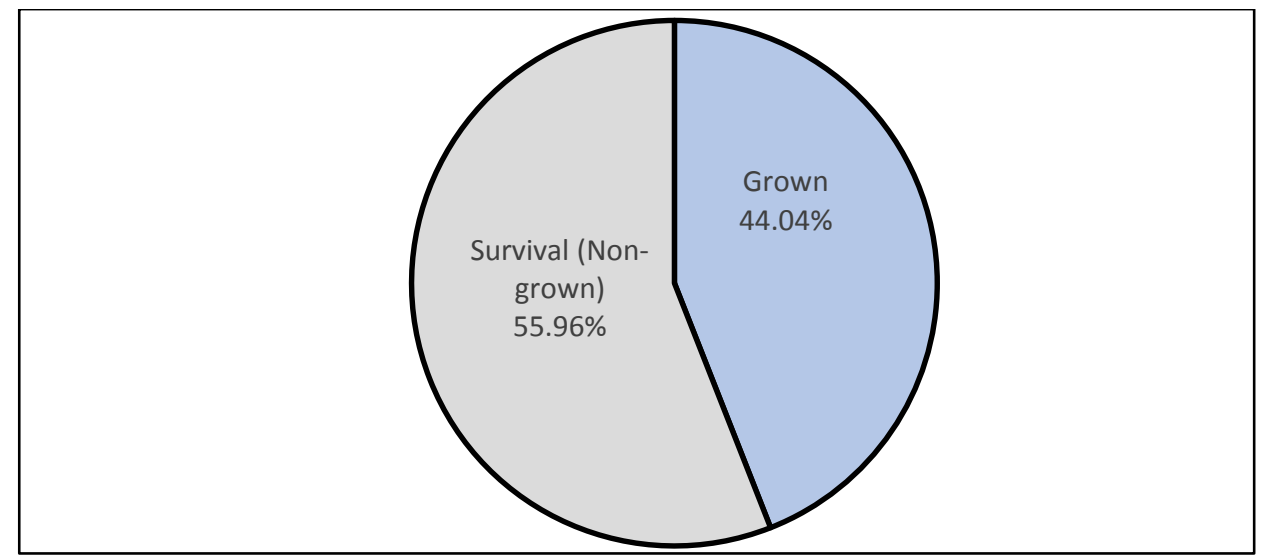

Figure 1. Status of manufacturing MSEs in selected towns of Central Zone of Tigray

As Figure 1, shows majority (55.96\%) of manufacturing MSEs are found nongrown type and only 44.04 percent (96) are found grown type. When looking at the growth situation of each enterprise separately, the following Table 2 indicated that from the surveyed 134 micro enterprises $38.06 \%$ (51 micro enterprises) are found grown type and the remaining 61.94\% (83 micro enterprises) are found survival type. Similarly, from the surveyed 84 small enterprises $53.57 \%$ (45 small enterprises) are found grown type and the remaining 46.43 percent ( 39 small enterprises) are found survival type. From this it is possible to conclude that manufacturing MSEs of the selected towns has shown a growing level from start to present in terms of increasing in number employees, even though there is a difference between these enterprises. Small enterprises show more growing status than that of micro enterprises.

Table 2. Growth situation of manufacturing MSEs in enterprise type wise in the selected towns

\begin{tabular}{|c|c|c|c|c|c|c|}
\hline \multirow{3}{*}{ Categories } & \multicolumn{4}{|c|}{ Enterprise type } & \multirow{2}{*}{\multicolumn{2}{|c|}{ Total }} \\
\hline & \multicolumn{2}{|c|}{ Micro } & \multicolumn{2}{|c|}{ Small } & & \\
\hline & Freq. & Percent & Freq & Percent & Freq. & Percent \\
\hline Grown & 51 & 38.06 & 45 & 53.57 & 96 & 44.03 \\
\hline Survival & 83 & 61.94 & 39 & 46.43 & 122 & 55.96 \\
\hline Total & 134 & 100.00 & 84 & 100.00 & 218 & 100.00 \\
\hline
\end{tabular}

Source: Own Survey (2019) 


\section{Growth situation of manufacturing MSEs in each of the selected towns}

Concerning to the growth situation of an enterprises in the selected towns comparatively, the following Table 3 indicated that from the surveyed 75,54,65 and 24 MSEs found in Adwa, Abiy Addi, Aksum and WukroMaray towns 66.67\% (50 enterprises), $31.48 \%$ (17 enterprises), 32.31\%(21enterprises) and 33.33\%(8 enterprises) are found grown type and the remaining 33.33\% (25 enterprises), 68.52\% (37 enterprises), $67.69 \%$ (44 enterprises), and 66.67\% (16 enterprises) are found survival type, respectively. Similarly, the average growth rate of manufacturing micro and small enterprises shows $21.30 \%, 20.50 \%, 19.40 \%$, and $17.40 \%$ for enterprises found in Adwa, Abiy Addi, WukroMaray, and Aksum towns, respectively.

From this it is possible to conclude that those manufacturing MSEs found in Adwa Town comparatively grow faster than enterprises found in other towns selected in this study and followed by enterprises operating in Abiy AddiTown. This is because, as it was observed in our field survey and communicated MSEs coordinator, manufacturing MSEs found in Adwa Town are clustered which in turn might be helped them to access enough working premise, market linkage, easy access to manufacturing inputs, etc as compared to other towns addressed in this study. Table 3. shows growth situation of manufacturing MSEs in each of the selected towns.

Table 3. Growth situation of manufacturing MSEs in each of the selected towns

\begin{tabular}{|c|c|c|c|c|c|c|c|c|c|}
\hline \multirow[b]{2}{*}{ Towns } & \multicolumn{2}{|c|}{ Grown } & \multicolumn{3}{|c|}{ Growth Rate } & \multicolumn{2}{|c|}{ Non-grown } & \multicolumn{2}{|c|}{ Total } \\
\hline & 它 & 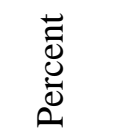 & $\dot{\Xi}$ & $\underset{\dot{\Xi}}{\stackrel{\dot{\Xi}}{\Sigma}}$ & 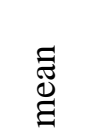 & $\underset{\dot{D}}{\dot{D}}$ & 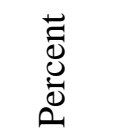 & 它 & $\begin{array}{l}\overrightarrow{0} \\
\stackrel{0}{0} \\
\stackrel{0}{0}\end{array}$ \\
\hline Aksum & 21 & 32.31 & 0.006 & 0.403 & 0.174 & 44 & 67.69 & 65 & 29.82 \\
\hline Adwa & 50 & 66.67 & 0.009 & 0.693 & 0.213 & 25 & 33.33 & 75 & 34.40 \\
\hline WukroMaray & 8 & 33.33 & 0.063 & 0.347 & 0.194 & 16 & 66.67 & 24 & 11.01 \\
\hline Abiy Addi & 17 & 31.48 & 0.013 & 0.549 & 0.205 & 37 & 68.52 & 54 & 24.77 \\
\hline Total & 96 & 100.00 & 0.006 & 0.693 & 0.201 & 122 & 100.00 & 218 & 100.00 \\
\hline
\end{tabular}

\section{MSEs growth and internal/owner related factors}

As it is discussed in the review of related literature part, internal/operators related factors are those of internal factors which may affect the growth of manufacturing MSEs internally. Several studies have been suggested various such factors including gender, age, education level, previous experience, initial investment size etc. In this section the growth of manufacturing MSEs in relation to gender, age, educational level, initial capital (investment) size and available machinery are discussed below.

\section{MSEs growth in relation to owners/operators gender and age}

Gender of the owner/operator was the first factor which expected to affect the growth of manufacturing MSEs. It is categorized in to male and female. In this study, out of the total surveyed MSEs (218), 189 (86.70 percent) were male headed and the rest 29 (13.30 percent) were female headed as described Table 4. This result is consistent with the findings of Mbugua, Mbugua, ,Wangoi, Ogada, \& Kariuki (2013) that found most (58.5) of the surveyed MSEs were male-headed and the remaining 41.5 were femaleheaded and Hailay (2014) also found 64 percent of the surveyed MSEs were male-headed and the remaining 36 percent were female-headed but contrary to studies of Mulu (2007), Habtamu (2012), Haftom (2013), and Kokobe (2011). 
In this survey also there is a difference in the average growth rate between the female owned manufacturing MSEs and the male owned manufacturing MSEs i.e., male owned manufacturing MSEs reveals a smaller mean growth rate (20\%), whereas the mean growth rate of female owned MSEs is higher (21.7\%). As a result, male owned Manufacturing MSEs have a smaller tendency of growth and are more of survival type as compared to female owned manufacturing MSEs. This may be due to the fact females take their business activities seriously and they may not incur extra unnecessary expenses as compared to male counterpart. Furthermore, the Chi-square analysis $\left(\mathrm{Chi}^{2}=5.37\right.$, $\mathrm{P}=0.02$ ) shows that there is a significant association between manufacturing MSEs growth and gender of the operators at 5 percent significance level.

This result is consistent to the findings of Chirwa (2008) which indicated that female-owned enterprises tend to grow more rapidly in terms of employment than maleowned ones, but it is in contrast with the empirical studies of Habtamu, (2012), Haftom (2013), Ishengoma \& Kappel (2008), Kokobe (2011), Hailay (2014) and Mulu (2007) which found that male owned firm's grow faster than that of female headed.

From this result it is possible to conclude that there is a difference in growth among these two groups (grown and survival) in terms of gender. Table 4 shows the overall relationship between the surveyed owners/operators gender and age, and manufacturing MSEs growth.

Table 4. Manufacturing MSEs growth in relation to owners/operators gender and age

\begin{tabular}{|c|c|c|c|c|c|c|c|c|c|c|c|c|}
\hline \multirow{3}{*}{ 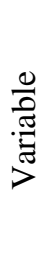 } & \multirow[b]{3}{*}{$\begin{array}{l}\text { Cate- } \\
\text { gories }\end{array}$} & \multicolumn{7}{|c|}{ Manufacturing MSEs Growth } & \multirow{2}{*}{\multicolumn{2}{|c|}{ Total }} & \multirow{3}{*}{$\mathrm{Chi}^{2}$} & \multirow{3}{*}{$\begin{array}{c}\text { P- } \\
\text { value }\end{array}$} \\
\hline & & \multicolumn{2}{|c|}{ Grown } & \multicolumn{3}{|c|}{ Growth Rate } & \multicolumn{2}{|c|}{ Non-grown } & & & & \\
\hline & & 它 & $\begin{array}{l}\overrightarrow{0} \\
\text { D. } \\
\text { ص. }\end{array}$ & $\dot{\Xi}$ & $\stackrel{\dot{z}}{\Sigma}$ & ฐ్ & 它 & 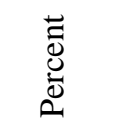 & 它 & 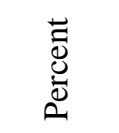 & & \\
\hline \multirow{3}{*}{$\begin{array}{l}\bar{\theta} \\
\stackrel{\vec{D}}{0} \\
0\end{array}$} & Male & 89 & 92.71 & 0.006 & 0.693 & 0.200 & 100 & 81.97 & 189 & 86.70 & \multirow[t]{3}{*}{$5.37 *$} & \multirow[t]{3}{*}{0.02} \\
\hline & Female & 7 & 7.29 & 0.040 & 0.549 & 0.217 & 22 & 18.03 & 29 & 13.30 & & \\
\hline & Total & 96 & 100.00 & 0.006 & 0.693 & 0.201 & 122 & 100 & 218 & 100 & & \\
\hline \multirow{6}{*}{$\stackrel{8}{\&}$} & $19-28$ & 30 & 31.25 & 0.034 & 0.693 & 0.266 & 44 & 36.07 & 74 & 33.94 & \multirow{6}{*}{0.78} & \multirow{6}{*}{0.94} \\
\hline & $29-38$ & 45 & 46.88 & 0.009 & 0.693 & 0.189 & 56 & 45.90 & 101 & 46.33 & & \\
\hline & $39-48$ & 16 & 16.67 & 0.009 & 0.346 & 0.152 & 17 & 13.93 & 33 & 15.14 & & \\
\hline & $49-58$ & 3 & 3.13 & 0.046 & 0.099 & 0.067 & 3 & 2.46 & 6 & 2.75 & & \\
\hline & $>58$ & 2 & 2.08 & 0.006 & 0.198 & 0.102 & 2 & 1.64 & 4 & 1.83 & & \\
\hline & Total & 96 & 100.00 & 0.006 & 0.693 & 0.201 & 122 & 100.00 & 218 & 100.00 & & \\
\hline
\end{tabular}

Source: Own Survey (2019)

*Significant at 5 percent level

Owner/operator age was the other factor which expected to determine manufacturing MSEs growth significantly but negatively. In order to clearly and precisely analyze and discuss the effect of owner/operator age on manufacturing MSEs growth, the continuous value of age is categorized in to five categories (i.e. 19-28, 29-38, 39-48, 4958 and greater than 58) by taking 10 value in between each category. Accordingly, Table 4 shows 74 (33.94 percent), 101 (46.33percent), 33 (15.14 percent), 6 (2.75 percent) and 4 (1.83 percent) of the surveyed MSEs were found within the age range of 19-28, 29-38, 39-48, 49-58 and greater than 58 years, respectively. Thus, most 101 (46.5 percent) of the sampled MSEs were found within the age range of 29-38.

As it is shown in the above Table 4, 78.13 percent of grown manufacturing MSEs are owned or operated by those individuals' age are in between 29-38 and 19-28 years with in $0.9-69.3$ percent growth rate. Similarly, they also take majority $(81.97 \%)$ of the 
survival manufacturing MSEs succeeded by 39-48 and49-58 that constitutes 19.8 percent of the grown manufacturing MSEs and 16.39 percent of the survival manufacturing MSEs. Therefore, most manufacturing MSEs are operated by whose age is between 2938 and 19-28. Similarly, the average growth rate is higher (26.6\%) for whose age is in between 19-28years and decreases as the age of operator is increases. From this we can understand that age of the owner/operator has an exact inverse relation with the growth of manufacturing MSEs. However, the Chi-square analysis $\left(\mathrm{Chi}^{2}=0.78, \mathrm{P}=0.94\right)$ shows that there is insignificant association between manufacturing MSEs growth and age of the owners/operators.

This result is consistent to the findings of Hailay (2014) that found age of the owner/operator is negatively affect growth of manufacturing MSEs that young owners grow faster than the old one and inconsistent to empirical studies of Mulu (2007), Habtamu (2012) and Haftom (2013) found that age of the owner/operator is not a significant factor affecting MSEs growth.

This may be due to the reason that the younger owner/operator has the necessary motivation, energy and commitment to work and is more inclined to take risks; a younger individual may have a higher need for additional income. In addition, the burden of supporting a family generally declines with age. That means the older owner/operator is likely to have reached his/her initial aspiration.

\section{Manufacturing MSEs growth in relation to owners/operators education level}

According to previous studies of McPherson (1996), Mulu (2007), and Habtanu (2012) in most developing countries the level education of MSEs operators is low. Similarly, the result of this study show that out of the total respondent 39.91, 28.44 and 22.48 percent of manufacturing MSEs operators are secondary education, college diploma/ TVET, primary education and above holders, respectively. The remaining 6.88 percent and 2.29 percent of sample populations are degree holders and illiterate, respectively. Table 5 summarizes the educational level of manufacturing MSEs owners.

Table 5. Manufacturing MSEs growth in relation to owners/operators education level

\begin{tabular}{|c|c|c|c|c|c|c|c|c|c|c|c|}
\hline \multirow[b]{3}{*}{ Categories } & \multicolumn{7}{|c|}{ Manufacturing MSEs Growth } & \multirow{2}{*}{\multicolumn{2}{|c|}{ Total }} & \multirow[b]{2}{*}{$\mathrm{Chi}^{2}$} & \multirow{2}{*}{$\begin{array}{c}\text { P- } \\
\text { value }\end{array}$} \\
\hline & \multicolumn{2}{|c|}{ Grown } & \multicolumn{3}{|c|}{ Growth Rate } & \multicolumn{2}{|c|}{ Non-grown } & & & & \\
\hline & 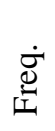 & 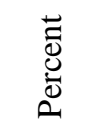 & $\dot{\Xi}$ & $\stackrel{\dot{x}}{\Sigma}$ & $\underset{\Xi}{\stackrel{\Xi}{\Xi}}$ & 总 & $\begin{array}{l}\overrightarrow{0} \\
\text { d. } \\
\text { D. }\end{array}$ & 迆 & 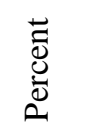 & & \\
\hline Illiterate & - & - & - & - & - & 5 & 4.10 & 5 & 2.29 & & \\
\hline Primary & 24 & 25.00 & 0.006 & 0.693 & 0.167 & 25 & 20.49 & 49 & 22.48 & & \\
\hline Secondary & 40 & 41.67 & 0.012 & 0.693 & 0.254 & 47 & 38.52 & 87 & 39.91 & & \\
\hline Coll. Dipl/TVET & 23 & 23.96 & 0.009 & 0.549 & 0.161 & 39 & 31.97 & 62 & 28.44 & 7.31 & 0.12 \\
\hline Degree \& Above & 9 & 9.38 & 0.034 & 0.274 & 0.161 & 6 & 4.92 & 15 & 6.88 & & \\
\hline Total & 96 & 100.00 & 0.006 & 0.693 & 0.201 & 122 & 100.00 & 218 & 100.00 & & \\
\hline
\end{tabular}

The secondary and primary education completes take the majority $(66.67 \%)$ of the grown manufacturing MSEs with 0.6-69.3 percent growth rate similarly secondary and College diploma/TVET holder takes majority (70.49\%) of the non-grown manufacturing MSEs succeeded by college diploma/TVET and degree and above holders that constitutes 33.34 percent of the growing manufacturing MSEs. Therefore, most manufacturing MSEs are operated by secondary education completes and college diploma holders. The average growth rate is higher $(25.4 \%)$ for secondary education completes and decreases for primary education complete, diploma/TVET and degree and above holders. However, the 
Chi-square analysis $\left(\mathrm{Chi}^{2}=7.31, \mathrm{P}=0.12\right)$ shows that there is no significant association between manufacturing MSEs growth and education level of the operators.

Moreover, the interview result shows that degree holders manufacturing MSEs mostly have an additional income from other activities such as from professional jobs and mostly they are opportunist i.e., they are engaged in many businesses. This implies that as the level of education increase the growth rate of manufacturing MSEs increase till some education level and then as education level further increases the growth of MSEs start to decline.

From this result it is possible to conclude that there is a difference in terms of growth among these two categories (grown and non-grown/survival) in terms of education level of the owner or operator, although the difference is insignificant according to Chi-square test statistics.

\section{Manufacturing MSEs growth in relation to initial investment size}

To start any business obviously it needs capital which may raise either from own saving or other sources such as family, relative, friend, Equb, Idir, microfinance, banks etc. The amount may again vary from firm to firm. To make this analysis short and clear, this variable was also grouped in to seven categories (less than or equal birr 1000, 10015000 , 5001-10000, 10001-25000, 25001-50000, 50001-100000 and greater than 100,000). The following Table 6 shows the comparison of grown and non-grown/survival manufacturing MSEs by using initial investment size.

Table 6. Manufacturing MSEs growth in relation to initial investment

\begin{tabular}{|c|c|c|c|c|c|c|c|c|c|c|c|}
\hline \multirow[t]{3}{*}{ Categories } & \multicolumn{7}{|c|}{ Manufacturing MSEs Growth } & \multirow{2}{*}{\multicolumn{2}{|c|}{ Total }} & \multirow[t]{2}{*}{$\mathrm{Chi}^{2}$} & \multirow{3}{*}{$\begin{array}{c}\text { P- } \\
\text { value }\end{array}$} \\
\hline & \multicolumn{2}{|r|}{ Grown } & \multicolumn{3}{|c|}{ Growth Rate } & \multicolumn{2}{|c|}{ Non-grown } & & & & \\
\hline & 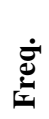 & 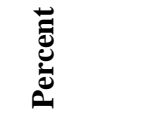 & $\dot{\Xi}$ & $\stackrel{\dot{a}}{\stackrel{\Xi}{\Sigma}}$ & $\underset{\Xi}{\mathbb{\Xi}}$ & 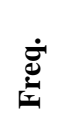 & 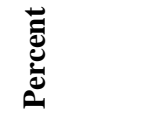 & 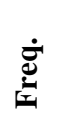 & 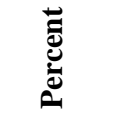 & & \\
\hline$<=1000$ & 4 & 4.17 & 0.006 & 0.268 & 0.173 & 5 & 4.10 & 9 & 4.13 & & \\
\hline $1001-5000$ & 19 & 19.79 & 0.034 & 0.693 & 0.160 & 28 & 22.95 & 47 & 21.56 & & \\
\hline $5001-10000$ & 26 & 27.08 & 0.009 & 0.693 & 0.194 & 26 & 21.31 & 52 & 23.85 & & \\
\hline $10001-25000$ & 22 & 22.92 & 0.041 & 0.549 & 0.236 & 37 & 30.33 & 59 & 27.06 & & \\
\hline $25001-50000$ & 16 & 16.67 & 0.013 & 0.549 & 0.218 & 18 & 14.75 & 34 & 15.60 & & \\
\hline $50001-100000$ & 7 & 7.29 & 0.009 & 0.549 & 0.216 & 4 & 3.28 & 11 & 5.05 & $9.64 * * *$ & 0.00 \\
\hline$>100000$ & 2 & 2.08 & 0.091 & $\mathbf{0 . 3 4 7}$ & 0.213 & 4 & 3.28 & 6 & 2.75 & & \\
\hline Total & 96 & 100.00 & 0.006 & 0.693 & 0.201 & 122 & 100.00 & 218 & 100.00 & & \\
\hline Mean & & $24,348.02$ & & & 0.201 & & $23,265.57$ & & $26,620.24$ & & \\
\hline SD & & $38,145.39$ & & & 0.154 & & 35035.95 & & $37,919.65$ & & \\
\hline Minimum & & 300 & & & 0.006 & & 300 & & 300 & & \\
\hline Maximum & & 300,000 & & & 0.693 & & 220,000 & & 300,000 & & \\
\hline
\end{tabular}

Source: Own Survey (2019)

*** Significant at 1percent level

Majority (27.08\%) of the growing manufacturing MSEs start operation with an initial investment size that ranges from birr 5001-10,000 while majority (30.33\%) of the survival manufacturing MSEs start operation with an initial investment size that ranges from birr 10,001-25,000. But most (88.07\%) manufacturing MSEs in this study start operation with an initial investment size that ranges from birr $1001-50,000$. The minimum initial investment size for all MSEs is birr 300 whereas the maximum initial investment size is birr 300,000 and the average initial investment size is birr 26,620.24. The initial investment size for the growing manufacturing MSEs is more variable and diverse as compared to the survival manufacturing MSEs as the SD of the initial investment shows in the Table 6. Similarly, the average initial investment size is higher for the grown manufacturing MSEs (birr 24,348.02) as compared to the survival/no- 
grown manufacturing MSEs average initial investment size (birr 23,265.57). The average growth rate is higher for those manufacturing MSEs that are started operation with an initial investment size that ranges from birr 10,001-25,000 and decrease for both those that start operation with an initial investment size that below birr 10,000 and over birr 25,000. Moreover, the Chi-square analysis $\left(\mathrm{Chi}^{2}=9.64, \mathrm{P}=0.00\right)$ shows that there is a significant association between manufacturing MSEs growth and initial investment of the operators at 1 percent significant level.

Therefore, this result is consistent with the finding of Habtamu (2012), Haftom (2013), and Dagmawit \& Yishak (2016) which stated that MSEs started with higher initial investment size were significantly more likely to grow than MSEs started with lower initial investment size. But, contrary to the results of Hailay (2014) reported that start- up capital of a given firm has insignificant effect on the growth of MSEs.

Generally, from this result, it can be summarized that the relationship between initial investment size and manufacturing MSEs growth rate in some extent positive as expected. This may be because larger in initial investment size are sufficient enough to carry out their business activities.

\section{Manufacturing MSEs growth in relation to modern machinery}

Availability of machinery is another factor which expected to positively affect the growth of manufacturing MSEs. Buyers need better products time after time. To produce quality product/better product, enterprises (especially, wood work and metal work) need modern machineries and equipment that is very crucial for producing quality output that is preferred by buyers. In this study it is categorized in to those which have modern machinery and those which have not it. Table 7 shows the comparison of grown and nongrown/survival manufacturing MSEs by using accessibility of machinery.

Table 7. Manufacturing MSEs growth in relation to modern machinery

\begin{tabular}{|c|c|c|c|c|c|c|c|c|c|c|c|}
\hline \multirow[b]{3}{*}{ Categories } & \multicolumn{7}{|c|}{ Manufacturing MSEs Growth } & \multirow{2}{*}{\multicolumn{2}{|c|}{ Total }} & \multirow[b]{3}{*}{$\mathrm{Chi}^{2}$} & \multirow{3}{*}{$\begin{array}{c}\text { P- } \\
\text { value }\end{array}$} \\
\hline & \multicolumn{2}{|c|}{ Grown } & \multicolumn{3}{|c|}{ Growth Rate } & \multicolumn{2}{|c|}{ Non-grown } & & & & \\
\hline & 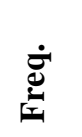 & 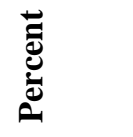 & $\dot{\Xi}$ & $\stackrel{\dot{z}}{\Sigma}$ & 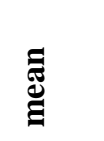 & 远 & 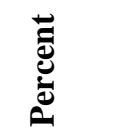 & 远 & 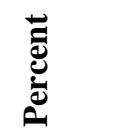 & & \\
\hline Available & 20 & 20.83 & 0.009 & 0.594 & 0.211 & 15 & 12.30 & 35 & 16.06 & & \\
\hline Not available & 76 & 79.17 & 0.006 & 0.693 & 0.198 & 107 & 87.70 & 183 & 83.94 & $2.90 *$ & 0.08 \\
\hline Total & 96 & 100.00 & 0.006 & 0.693 & 0.201 & 122 & 100.00 & 218 & 100.00 & & \\
\hline
\end{tabular}

As indicated in the Table 7, 20.83\% of the growing manufacturing MSEs and $12.30 \%$ of the survival MSEs have machinery in their business operation. Majority (79.17\%) of the grown manufacturing MSEs and majority (87.70\%) of the survival/nongrown MSEs have not machinery in their manufacturing activities. On the contrary, the average growth rate is higher $(21.10 \%)$ for those manufacturing MSEs which have machinery and (19.80\%) for those manufacturing MSEs which have not it.Furthermore, the Chi-square analysis $\left(\mathrm{Chi}^{2}=2.90, \mathrm{P}=0.08\right)$ shows that there is a significant association between manufacturing MSEs growth and availability of machinery at 10 percent significance level. From this one can understand that those manufacturing MSEs that have machinery have shown higher growth and expansion comparatively.

Therefore, this result is consistent with the finding of Belay, Asmera \& Tekalign (2015), which stated that MSEs have the required modern machinery were significantly more likely to grow than MSEs have not modern machinery. Thus, from this result it is 
comparatively possible to conclude that lack of working machinery was one the impeding challenge faced by most manufacturing MSE, although it can be summarized as manufacturing MSEs get modern machinery for their manufacturing activities, the probability of manufacturing enterprise growth increases.

\section{MSEs growth and external factors}

\section{Manufacturing MSEs growth in relation to work premises and training}

A work premise is another factor which expected to affect the growth of manufacturing MSEs positively. In this study it is categorized in to own enough work premises and own not enough work premise. In this study, out of the total surveyed manufacturing MSEs, 6.88\% were have enough work premises for their business operation and $93.12 \%$ are not have enough work premises as described Table 8. Majority (92.71\%) of the grown manufacturing MSEs and majority (93.44\%) of the survival MSEs not have enough work premises. Only $7.29 \%$ of the grown manufacturing MSEs and $6.56 \%$ of survival/ non-grown manufacturing MSEs have enough work premises to carry out their business. Thus, it is possible to say that still lack of working place for manufacturing micro and small enterprise is immense. However, the association between work premises and growth of manufacturing MSEs is not statistically significant according to the Pearson chi-square test statistics $\left(\mathrm{Chi}^{2}=0.05, \mathrm{P}=0.83\right)$.

Even though, it is statistically insignificant, from the result it is possible to conclude that those manufacturing MSEs that have work premises are most probably growing as compared to non-grown or survival MSEs and positively related to manufacturing MSEs growth. The following Table 8 shows the comparison of grown and non-grown/survival manufacturing MSEs by using work premises and training.

Table 8.Manufacturing MSEs growth in relation to work premises and training

\begin{tabular}{|c|c|c|c|c|c|c|c|c|c|c|c|c|}
\hline \multirow{3}{*}{ 苟 } & \multirow[b]{3}{*}{ Categories } & \multicolumn{7}{|c|}{ Manufacturing MSEs Growth } & \multirow{2}{*}{\multicolumn{2}{|c|}{ Total }} & \multirow[b]{3}{*}{$\mathrm{Chi}^{2}$} & \multirow[b]{3}{*}{$\begin{array}{c}\text { P- } \\
\text { value }\end{array}$} \\
\hline & & \multicolumn{2}{|c|}{ Grown } & \multicolumn{3}{|c|}{ Growth Rate } & \multicolumn{2}{|c|}{ Non-grown } & & & & \\
\hline & & $\dot{\vec{d}}$ & 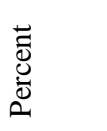 & $\dot{\Xi}$ & $\stackrel{\dot{x}}{\Sigma}$ & $\underset{\mathrm{\Xi}}{\stackrel{\Xi}{\Xi}}$ & 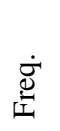 & $\begin{array}{l}\overrightarrow{0} \\
\text {.0. } \\
\text { 2. }\end{array}$ & 它 & 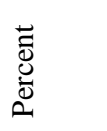 & & \\
\hline \multirow{3}{*}{ 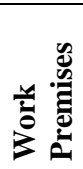 } & Enough & 7 & 7.29 & 0.012 & 0.255 & 0.144 & 8 & 6.56 & 15 & 6.88 & 0.05 & 0.83 \\
\hline & Not enough & 89 & 92.71 & 0.006 & 0.693 & 0.205 & 114 & 93.44 & 203 & 93.12 & & \\
\hline & Total & 96 & 100.00 & 0.006 & 0.693 & 0.201 & 122 & 100.00 & 218 & 100.00 & & \\
\hline \multirow{3}{*}{ } & Trained & 17 & 17.71 & 0.006 & 0.549 & 0.208 & 9 & 7.38 & 26 & 11.93 & $5.45^{*}$ & 0.01 \\
\hline & Not trained & 79 & 82.29 & 0.009 & 0.693 & 0.167 & 113 & 92.62 & 192 & 88.07 & & \\
\hline & Total & 96 & 100.00 & 0.006 & 0.693 & 0.201 & 122 & 100.00 & 218 & 100.00 & & \\
\hline
\end{tabular}

Source: Own Survey (2019)

*Significant at 5 percent level

As indicated in Table 8 , about $88.07 \%$ of manufacturing MSEs owners were not participated in business training and $11.93 \%$ of them were participated in the training. Only $17.71 \%$ of the growing manufacturing MSEs and $7.38 \%$ of survival/non-grown manufacturing MSEs owners participated in training. Among the non-growing manufacturing MSEs 65\% were not trained and 7.38\% were trained. Chi-square test of business training between the two groups was run and the difference was found to be statistically significant at $1 \%$ level of significance. This result is consistent with the findings of Dagmawit \& Yishak, (2016) who found significant association between business training of the owner and growth of manufacturing MSEs. However, it is 
inconsistent with the findings of Garoma (2012) who found insignificant association between business training of the owner and success of micro enterprises.

Therefore, from these results it is possible to conclude that training conducted to micro and small enterprises is still inadequate to perform well in the enterprise business, despite startup training is given for most of manufacturing MSE. In addition, as asserted by interviewee, most likely inadequacy of training resulted from both by quality of training and shortage of duration of training.

\section{Manufacturing MSEs growth in relation to market linkage and infrastructural access}

Access to market linkage was another variable which expected to have a positive relationship with growth of manufacturing MSEs. According to Table 9, majority $(87.50 \%)$ of the growing manufacturing MSEs and majority $(80.33 \%)$ of the survival MSEs have not market linkage with other firms/institutions. Only $12.50 \%$ of the growing manufacturing MSEs and 19.67\% of survival/ non-grown manufacturing MSEs have market linkage.Similarly, the MSEs that have a market linkage with firms reveal the $21.20 \%$ average growth rate. $83.49 \%$ percent of the growing and the survival manufacturing MSEs have no market linkage. This is consistent with Eshetu \& Mammo (2009) and Habtamu (2012) study that found most MSEs in Ethiopia has poor market linkage.

This is may be due to the fact that most manufacturing MSEs sell their products to customers around their working place or to any person that comes to their market area. In addition, the demand for the MSEs products and the supply of raw material to MSEs may not be consistent. Similarly, the association between market linkage and growth of manufacturing MSEs is not statistically significant according to the Pearson chi-square test statistics $\left(\mathrm{Chi}^{2}=2.00, \mathrm{P}=0.157\right)$. But this doesn't mean that market access/linkage and manufacturing MSEs growth has no association, rather in this particular study area its effect is statistically insignificant. From this result it is possible to conclude that there is a difference in terms of growth among these two groups (grower and non-grower) in terms of market linkage, although the difference is insignificant according to Chi-square test statistics. Table 9 shows the details of market linkage and infrastructure result.

Table 9. Manufacturing MSEs growth in relation to market linkage and infrastructure

\begin{tabular}{|c|c|c|c|c|c|c|c|c|c|c|c|c|}
\hline \multirow{3}{*}{ 尝 } & \multirow[b]{3}{*}{ Categories } & \multicolumn{7}{|c|}{ Manufacturing MSEs Growth } & \multirow{2}{*}{\multicolumn{2}{|c|}{ Total }} & \multirow[b]{3}{*}{$\mathrm{Chi}^{2}$} & \multirow[b]{3}{*}{$\begin{array}{c}P- \\
\text { value }\end{array}$} \\
\hline & & \multicolumn{2}{|c|}{ Grown } & \multicolumn{3}{|c|}{ Growth Rate } & \multicolumn{2}{|c|}{ Non-grown } & & & & \\
\hline & & $\dot{\Phi}$ & 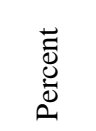 & $\dot{\Xi}$ & $\stackrel{\dot{u}}{\Sigma}$ & 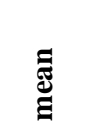 & 它 & $\begin{array}{l}\overrightarrow{0} \\
\stackrel{0}{0} \\
\stackrel{0}{0}\end{array}$ & 它 & 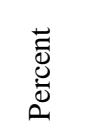 & & \\
\hline \multirow{3}{*}{ 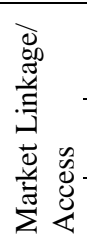 } & $\begin{array}{l}\text { Have } \\
\text { access }\end{array}$ & 12 & 12.50 & 0.009 & 0.321 & 0.212 & 24 & 19.67 & 36 & 16.51 & \multirow{3}{*}{2.00} & \multirow{3}{*}{0.157} \\
\hline & $\begin{array}{l}\text { Not have } \\
\text { access }\end{array}$ & 84 & 87.50 & 0.006 & 0.693 & 0.125 & 98 & 80.33 & 182 & 83.49 & & \\
\hline & Total & 96 & 100 & 0.006 & 0.693 & 0.201 & 122 & 100 & 218 & 100 & & \\
\hline \multirow{3}{*}{ 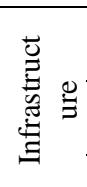 } & $\begin{array}{l}\text { Enough } \\
\text { infra }\end{array}$ & 75 & 78.13 & 0.006 & 0.693 & 0.213 & 76 & 62.30 & 151 & 69.27 & \multirow{3}{*}{$6.32 *$} & \multirow{3}{*}{0.01} \\
\hline & $\begin{array}{l}\text { Not } \\
\text { enough }\end{array}$ & 21 & 21.87 & 0.009 & 0.462 & 0.159 & 46 & 37.70 & 67 & 30.73 & & \\
\hline & Total & 96 & 100.00 & 0.006 & 0.693 & 0.201 & 122 & 100.00 & 218 & 100.00 & & \\
\hline
\end{tabular}

Source: Own Survey (2019)

*Significant at 5 percent level

Access to infrastructure was also the other external factors which expected to positively affect the growth of MSEs. The specified factors in relation to this variable are 
insufficient and interruption of power, insufficient and interruption of water supply, insufficient and interruption of communication services, insufficient and inconvenient road and lack of sufficient and quick transportation. Here respondents were also asked to state whether these all infrastructures are sufficient enough to carry out their business operation or not. Then as indicated in the Table 9 above, majority $(78.13 \%)$ of the growing manufacturing MSEs and majority (62.30\%) of the survival MSEs have enough to infrastructure facilities in their business operation. The remaining $(21.87 \%)$ of the growing manufacturing MSEs and 37.70\% of the survival/non-grown MSEs have not enough access to infrastructure facilities in their manufacturing activities. Similarly, the average growth rate is higher $(21.30 \%)$ for those manufacturing MSEs which are enough access to infrastructure and (15.90\%) for those manufacturing MSEs which are not access to it.Furthermore, the Chi-square analysis $\left(\mathrm{Chi}^{2}=6.32, \mathrm{P}=0.01\right)$ shows that there is a significant association between manufacturing MSEs growth and enough access to the required infrastructure facilities at 10 percent significance level.

This result is consistent with the findings of Hailay (2014), Admasu (2012), Clover \& Darroch (2005), Haftom (2013), Kinda \& Loening (2008), and Osotimehin, Jegede, , Akinlabi, \& Olajide (2012) which revealed that infrastructure such as, inability to access power, water, road etc has a significant impact on the growth of MSEs.

\section{Manufacturing MSEs growth in relation to location}

Table 10, shows the comparison of grown and non-grown/survival manufacturing MSEs by using location.

Table 10. Manufacturing MSEs growth in relation to location of enterprises

\begin{tabular}{|c|c|c|c|c|c|c|c|c|c|c|c|}
\hline \multirow[b]{3}{*}{ Categories } & \multicolumn{7}{|c|}{ Manufacturing MSEs Growth } & \multirow{2}{*}{\multicolumn{2}{|c|}{ Total }} & \multirow[b]{3}{*}{$\mathrm{Chi}^{2}$} & \multirow{3}{*}{$\begin{array}{c}\text { P- } \\
\text { value }\end{array}$} \\
\hline & \multicolumn{2}{|c|}{ Grown } & \multicolumn{3}{|c|}{ Growth Rate } & \multicolumn{2}{|c|}{ Non-grown } & & & & \\
\hline & $\dot{\Xi}$ & 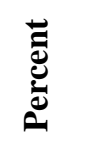 & $\dot{\Sigma}$ & $\stackrel{\dot{x}}{\Sigma}$ & 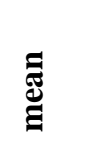 & 远 & 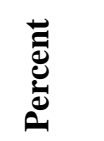 & $\dot{\vec{J}}$ & 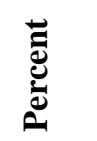 & & \\
\hline On main road & 59 & 61.46 & 0.006 & 0.549 & 0.179 & 88 & 72.13 & 147 & 67.43 & & \\
\hline Out of main road & 37 & 38.54 & 0.034 & 0.693 & 0.235 & 34 & 27.87 & 71 & 32.57 & $2.78 *$ & 0.09 \\
\hline Total & 96 & 100 & 0.006 & 0.693 & 0.201 & 122 & 100 & 218 & 100 & & \\
\hline
\end{tabular}

Source: Own Survey (2019)

*Significant at 10 percent level

MSEs operate either at the main road side or out of main road. As indicated in the Table 10, in this study about 61.46 percent of the grown and 72.13 percent of the survival manufacturing MSEs operates around the main road/street. Only 38.54 and 27.57 percent of the grown and the survival manufacturing MSEs operates out of main road, respectively. There is also a difference in the growth rate between manufacturing MSEs that operate around the main road and out of the main road. Manufacturing MSEs that operates out of the main road shows higher growth (23.50\%) than manufacturing MSEs that operates around the main road (17.90\%). This may be due to manufacturing MSEs have an easy access for input at out of main road as compared to those MSEs operating around the main road. Moreover, the Pearson chi-square statistics $\left(\mathrm{Chi}^{2}=2.78 \mathrm{P}=0.09\right)$ shows that there is significant association between growth of manufacturing MSEs and location. This result is consistent with previous study of Habtamu (2012), but contrary to study of Mead \& Leidholm (1998) and Liedholm (2002). 


\section{CONCLUSIONS AND RECOMMENDATIONS}

\section{Conclusions}

Majorities (61.47\%) of the MSEs in the selected towns of central zone of Tigray region were micro enterprise and the remaining $(38.53 \%)$ were small enterprises. It has been found that about $55.96 \%$ of enterprise that are survival/non-grown MMSEs and the remaining 44.04\% are growing manufacturing MSEs. Concerning to the growth situation of an enterprises, the average growth rate of manufacturing micro and small enterprises shows $21.30 \%, 20.50 \%, 19.40 \%$, and $17.40 \%$ for enterprises found in Adwa, Abiy Addi, WukroMaray, and Aksum towns, respectively.

To a very slight extent female-headed manufacturing MSEs seem grow faster than male-headed. Relating to the age of the owner/operator, the findings suggest that the age of the owner/operator is negatively associated with manufacturing MSE growth. The growth rate of manufacturing MSEs that were owned/operated by those whose age ranges from 19-28 years is higher than those whose age ranges from 29-38, 39-48 and >58 years and manufacturing MSEs that were owned/operated by those whose age is 49-58 years show a least growth rate.

The manufacturing MSEs that owned/operated by those who have a secondary education level completed were shown higher growth rate and followed by those who have completed primary grades, TVET/diploma and degree completed, while all of manufacturing MSEs that owned/operated by those of illiterate were non-growing. To conclude, there is no significant association in the growth of manufacturing MSEs in relation to the education level of the owner/operator.

Manufacturing MSEs that start operation with an initial investment size that ranges from birr 10,001-25,000 shows the highest growth rate as compared to those which start operation with an initial investment size that exceed 25,000 birr. The growth rate and initial investment size have an inverse relationship as the initial investment size exceed 25,000 birr.In relation to availability of machinery, those manufacturing MSEs have modern machinery shows higher mean of growth rate than those manufacturing MSEs has not the required machinery.

Training, infrastructure, market linkage, location and access to work premises (including difficulty to obtain working premises, inadequate and inconvenient working premises and high rent paid for working premises) were found as significant factors associated with the growth of manufacturing MSEs.

There is a big difference in mean growth rate among the manufacturing MSEs that are operating at main road side (busy street) and out of town (distant areas). The manufacturing MSEs that are operating at out of town shows the highest growth rate as compared to those that are operating at main road side. Further, the manufacturing MSEs that have a market linkage show the highest growth rate as compared to those which have no realizable market linkage/poor market linkage.In addition, infrastructural factors such as, insufficient and interruption of power, water supply, lack of sufficient and quick transportation and inconvenient road were the other external factors associated with the growth of manufacturing MSEs positively.

\section{Recommendations}

Male owned manufacturing MSEs grow faster than female owned manufacturing MSEs. Hence, the financial institution, trade and industry, women affairs and MSEs development office have to raise awareness, affirmative action and business development service by using different mechanisms such as using print and air media. Besides, education and training are required to raise awareness about how to use the profit for the 
expansion of the business, engage in more profitable manufacturing firm and opportunities of taking loan. This will increase growth manufacturing MSEs owned by female.

Working premise is found to have significant positive impact on manufacturing MSEs growth. Therefore, the MSEs development office in collaboration with the municipality should strive for the manufacturing MSEs to have own working premise or construct shades and avail them at fair rent. This can be achieved by creating manufacturing MSEs working and marketing place in selected area as clusters rather than operating in a scattered manner. The other external factor that significantly determines growth of manufacturing MSEs is business training. Therefore, MSEs agency and MSEs center leaders have to devote more in working with technical and vocational education training (TVET) colleges to solve skill gaps of entrepreneurs operating in manufacturing MSEs sector. The other thing needs consideration is infrastructure facility. Therefore, regional government and partly zonal administrative should pay attention to the improvement of infrastructures such as roads, electricity, water and access to information on business opportunities. Particularly, MSEs development agencies in collaboration with the towns water resources bureau, the Ethiopian Electric Power Corporation and regional road and transport to solve the problem of interruption and inadequacy of these facilities.

Most manufacturing MSEs are located at main road side in which there is high competition and practice of copycat strategy. Therefore, the organizations that are concerned with promotion and development of MSEs have to inform the manufacturing MSEs operators about the opportunities and challenges of being located at main road side (busy street) and out of town (distant areas) through workshops, seminars, education and training to enhance the growth of manufacturing MSEs, and develop market around their business operation for those MSEs interested to locate their business in periphery or create market linkage.

To solve this problem, MSEs development agency of the selected towns needs to change the perception of the general public on local goods through extensive awareness creation mechanisms and motivation; and linking the manufacturing MSEs with suppliers working within or around the town. In addition, enterprises themselves could form market linkage at trade exhibition and bazaar by presenting their goods and then exchanging their addresses with potential and actual customers there. Enterprises can have forward linkage with customers or other resellers and backward linkage with their raw material suppliers to get needed quality and quantity of the materials which in turn help to produce quality goods that could satisfy customer's needs and wants. If customers are satisfied, they buy repetitively the enterprise's product and promote it. This also will result in an increase of manufacturing enterprise growth.

\section{REFERENCES}

Admasu, A. (2012). Factors affecting the performance of MSEs in Arada and Lideta subcities, Addis Ababa. (Master's thesis). Addis Ababa University, Addis Ababa, Ethiopia.

Ahiawodzi, A., \& Adabe, T. (2012). Access to credit and growth of small and medium scale enterprises in the Ho Municipality of Ghana. British Journal of Economics, Finance and Management Sciences, 6 (2), 1-18.

Amha, W., \& Ageba, G. (2006). Business Development Services in Ethiopia: Status, Prospects and Challenges in the Micro and Small Enterprise Sector. International Journal of Emerging Markets, 1(4), 305 - 328. 
Arega, S., Muhammed, A., \& Daniel T. (2016). Growth of Micro and Small Enterprises in Addis Ababa City Administration: A Study on Selected Micro and Small Enterprise in Bole Sub City. International Journal of Scientific and Research Publications, 6(1), 581 - 592

Assefa, B., Zerfu, A., \& Tekle, B. (2014). Identifying key success factors and constraints in Ethiopia's MSE Development: An exploratory research, Ethiopia Development Research Institute, Addis Ababa

Belay, K., Asmera, T., \& Tekalign, M. (2015). Factors that affect developments of micro and small enterprises in the Case of Mettu, Hurumu, Bedelle and Gore Towns of Ilu Aba Bora Administrative Zone: International Journal of Scientific and Research Publications, 5(1), 1 - 10

Bereket, T. (2010). The Role of Micro and Small Enterprises in Employment Creation and Income Generation: A Survey Study of Mekelle City, Tigray Region, Ethiopia, (Master's thesis). Addis Ababa University, Addis Ababa, Ethiopia.

Berhanu, T. (2014). The assessment of factors that affect the growth and success of MSEs in Gurage Zone three selected Woredas. (Master's thesis). Mekelle University, Ethiopia

Berihu, A., Abebaw Z., \& Biruk T. (2014). Identifying key success factors and constraints in Ethiopia's MSE development: An exploratory research. EDRI Research Report 18. Addis Ababa: Ethiopian Development Research Institute

Bizusew, K. (2015): The Challenges of Micro and Small Enterprises and Business Development Service: (Master's thesis). Addis Ababa University.

Central Statistical Agency. (2003). Urban informal sector sample survey. Addis Ababa, Ethiopia. Statistical Survey, Annual Report.

Cheng, W. (2006). Determinants of growth in small and medium enterprise: An empirical study on logistic industry in Hongkong. (Doctoral thesis). Curtin University of Technology. Available at: http://espace.library.curtin.edu.au/R/ ?func=dbin-jumpfull\&object_id=18498\&local_base=GEN01-ERA02

Dagmawit, A., \& Yishak, G. (2016). Determinants of Micro and Small Enterprises Growth: The Case of Durame Town, Kembata Tembaro Zone, Southern Nations and Nationalities and Peoples Region, Ethiopia. International Journal of Business and Economics Research. 5(5), 161-175

Deribie, E.,Nigusse, G., \& Mitiku,F. (2013). Filling the breach: microfinance, Journal of business and economics management, 1(11), 10-17

Desalegn, B. (2013). Challenges and Opportunities of Micro and Small Manufacturing Enterprises the Case of Easter Zone of Tigray: International Journal of Science and Research, 5(6), 1679-1686

FDRE Ministry of Trade and Industry, (1997), Micro and Small Enterprises Development Strategy Addis Ababa: Ministry of Trade and Industry.

Federal Micro \& Small Enterprises development Agency (2011). Micro and Small Enterprises Development Strategy, Provision Framework and Methods of Implementation. Addis Ababa, Ethiopia. Unpublished Report

Garoma, B. (2012). Determinants of microenterprise success in the urban informal sector of Addis Ababa: (Doctoral Dissertation). Erasmus University Rotterdam.

Gebreyesus, M. (2007). Growth of micro-enterprises: Empirical evidence from Ethiopia. [Online] Ethiopian Development Research Institute (EDRI). http://www.csae.ox.ac.uk/confer ences/2007-EDiALaWBiDC/ papers/275Gebreeyesus. pdf (Accessed on 11 June 2011). 
Gujarati, D. (2004). Basic Econometrics (4 ${ }^{\text {th }}$ ed.). New York, NY: McGraw-Hill companies.

Habtamu, T. (2012). Determinants of micro and small enterprises growth in Tigray regional state: Evidence from Mekelle city. (Master's thesis). University of Mekelle). Mekelle, Ethiopia.

Haftom, H. (2013). Factors affecting the growth of micro and small enterprises in shire Indaselassie town. (Master's thesis). University of Mekelle. Mekelle, Ethiopia.

Hailay, A. (2014). Determinants of Micro and Small Enterprises Growth in Feresmay Town, Tigray: (Master Thesis). Mekelle University, Mekelle, Ethiopia.

Hasnu, S., \& Amjam, S. (2007). Factors determining success of microenterprises: Evidence from district Peshawar. Gomal University Journal of Research, 23, 3845.

Hosmer, D., \& Lemeshow, S. (1980). A goodness of fit test for the multiple logistic regression model. Communications in Statistics Journal, 10 (1), 1043-1069.

Hove, P. \& Tarisai, C. (2013). Internal factors affecting the successful growth and survival of small and micro agri-business firms in Alice communal area. Journal of Economics, 4(1), 57-67.

Ishengoma, E. \& Kappel, R. (2008). Business constraints and growth potential of micro and small manufacturing enterprises in Uganda. GIGA Journal of Research Programme, 5(78), 1-29..

Kefale, M., \& Chinnan, K. (2012). Employment growth and challenges in small and micro enterprises in Woldiya. Educational Research and Essays, 1(2), 21 - 26.

Kidane, A., Hepelwa, K. Mdadila, H., \& Leel, A. (2015). Assessment of the social and economic role of MSEs in Tabora, Tanzania Journal of Development and Agricultural Economics, 7(2), $72-79$

Kinda, T. \& Loening, J. (2008). Small enterprise growth and therural investment climate: Evidence from Tanzania. Policy Research Working Paper Series 4675, The World Bank.

Kokobe, S. (2013). Determinants of micro and small enterprises growth: the case of Addis Ababa MSEs. (Master's thesis), University of Addis Ababa. Addis Ababa, Ethiopia

Lilian, K. (2013). Factors Influencing The Growth Of Youth Owned Micro And Small Entreprises In Tigania West Division, Meru County, Kenya. (Master Thesis): University Of Nairobi

Mbugua, J., Mbugua, S.,Wangoi, M., Ogada, J., \& Kariuki, J. (2013). Factors affecting the growth of micro and small enterprises: A Case of Tailoring and Dressmaking Enterprises in Eldoret, Kenya.International Journal of Business and Social Science, 4 (5), 1-9.

McPherson, M. (1996). Growth of micro and small enterprises in South Africa. Journal of Development Economics, 48 (2), 253-277.

Mead, C., \& Liedholm, C. (1998). Dynamics of micro and small enterprises in developing countries. World development, 26(1), 61-74.

MoFED (Ministry of Finance and Economic Development), (2010). Growth and Transformation Plan of Ethiopia 2010/11-2014/15. Addis Ababa.

MoTI (Ministry of Trade and Industry). (2011). Micro and Small Enterprises Development Strategy. Addis Ababa, Ethiopia.

Mukund, C. (2013). Challenges and Opportunities in Micro, Small and Medium Enterprises in India: International Conference on Management, Humanity and Economics 
Mulu, G. (2007). Growth of Micro-Enterprises: Empirical evidence from Ethiopia. Ethiopian Development Research Institute (EDRI), Ethiopia.

Netsaalem, B. (2011). Factors Affecting The Performance Of Micro And Small Enterprises: The Case Of Harar, Ethiopia: (Master's thesis). Haramaya University. Ethiopia.

Osotimehin, O., Jegede, A., Akinlabi, H., \& Olajide,T. (2012). An Evaluation of the Challenges and Prospects of Micro and Small-Scale Enterprises Development in Nigeria. American International Journal of Contemporary Research, 2(4), 174-185

Parker, J. (1995). Patterns of business growth: Micro and small enterprises in Kenya. (Doctoral dissertation). Michigan State University, East Lansing, Michigan.

Ruth, N. (2013). Factors Influencing Growth of Women owned Micro and Small Enterprises: A Survey of Kitale Municipality.International Journal of Academic Research in Business and Social Sciences, 3 (10), 182-196

Saravanan, K., Mohideen, M., \& Seid, H. (2014). Nature and characteristics of MSEs in India. International Journal of Scientific and Research Publications, 4 (8), 22-38

Selamawit, N., Aregawi, G., \& Nigus, A., (2014). Determinants of Access to finance for MSEs.

Sherefa, M. (2012). Performance of Micro and Small Enterprises and their Role in Enhancing Local Economic Development: A Case Study in Gullele Sub City of Addis Ababa. (Master's thesis). Addis Abeba University.

Tasisa, A. (2014). The Contribution of Micro and Small Enterprises in Community Development in Addis Ababa Gullele Sub City. Master's thesis, Addis Ababa University

Worku, S. (2004). Socio- economic determinants of growth of small manufacturing enterprises in Addis Ababa, (Master's thesis). Addis Ababa University

Zemenu, A., \& Mohammed, M. (2014). Determinants of Growth of Micro and Small Enterprises in ETHIOPIA: A Case of MSEs in Mekelle City, Tigray. International Journal of Advance Research in Computer Science and Management Studies, 2(6), $149-157$

(C) 2020 by the authors. Licensee JPPD, Indonesia. This article is an open access article distributed under the terms and conditions of the Creative Commons Attribution (CC BY) license (http://creativecommons.org/licenses/by/4.0/). 